\title{
Revenue potential Retribution (Case Study Cianjur District)
}

\author{
By: Yuyus Yudistria \\ Bandung West Java Indonesia \\ y.yudistria@yahoo.com
}

\begin{abstract}
The problem of this study is to identify the type of potential retribution improved in Cianjur and doing Projection types levies in Cianjur. The model used to look at the sources of potential retribution by using a matrix potential is based on the calculation of the levy revenue realization growth and the contribution of each type of levy on total revenues levy, whereas to get numerical value of the projected levy used ARIMA projection method is often called method Box-Jenskins time series, the results of the processing of potential types of levies are included in the category of seed / Prima there are 4 types of levies such as: Market services; Retribution Recreation and Sports; Building Permit levy and Disturbance Permits. While that fall into the category of the most underdeveloped. Results of the projection processing on the type of retribution then the contribution levy is expected to rise high enough levies building permit (IMB)
\end{abstract}

Keywords : Retribution, Potency, Projection

\section{INTRODUCTION}

One source of revenue (PAD) is a levy. PAD is a regional income sourced from the local tax, the result of retribution, the results of which are separated regional wealth management and other legitimate PAD which aims to provide flexibility to the regions in tapping funds in the implementation of regional autonomy as the realization of the principle of decentralization. In addition to balancing revenues and funds, local governments can also receive grants and obtain financing from domestic and abroad, such as bonds and foreign loans despite having received permission from the government

Determination of the type of levy has been set in the Act No. 28 of 2009. The provision of discretion in setting the new levies were originally based on the state of the area that has the potential sources of revenue are very diverse so it is difficult to accommodate overall in the Act

City / Municipality Government needs to carefully analyze the potential levy under its authority. So the potential levies to boost revenue. Through careful analysis is expected to help unravel the problems of retribution, can know the potential pencapatan future retribution, as well as the strategies and policies needed to increase the potential for retribution.

There are some of the most fundamental issues in levies that affect the PAD revenues do not reach the target optimally, both in the intensification and extension of the problems that such a policy, facilities / infrastructure, human resources, targeting and other issues .

Aims

1. Identify the types of potential retribution improved in Cianjur

2. Projection types of levies in Cianjur

\section{METHODS}

Levy Mapping Analysis of Potential

Levy mapping model used is a model typology Klassen, this model is used to look at the sources of potential retribution by using a matrix potential is based on the calculation of the levy revenue realization growth and the contribution of each type of levy on the total revenue levy. By using the potential of the matrix can be determined category types of levy into the income levy Prima, Potential, Developing and Least Developed (DR Mulyanto, 2002) with the following stages:

Calculating the ratio between the Contributions of a type of retribution with an average contribution of levy (Contributions Ratio). The calculation result will show the figures are smaller than $1(<1)$, equal to $1(=1)$ and greater than 1 (> 1).

Potential Matrix compiled based Ratio Growth and Ratio Contributions, to obtain Prima criteria (PRM), Potential (POT), Developing (BKB) and Retarded (TBLK) Table 1 Matrix Typology Klassen

\begin{tabular}{|l|l|l|} 
Ratio Growth & $C^{B} \leq 1$ & $\frac{C^{j}}{C^{B}}>1$ \\
\hline$\frac{r^{j}}{r^{B}} \leq 1$ & Retarded & Potential \\
\hline$\frac{r^{j}}{r^{B}}>1$ & Developing & Prima criteria \\
\hline
\end{tabular}

Specification:

$\mathrm{Rj}=$ rate of growth of certain levies type

$\mathrm{CJ}=$ Contributions One type specific levy

$\mathrm{rB}=$ Local Revenue Growth Rate in Cianjur

$\mathrm{CB}=$ Contributions Local Revenue in Cianjur

\section{Projection Levy}

To obtain the numerical value of the projected levy in 2015-2020 used ARIMA projection method is often also called the method of time series Box-Jenskins. Autoregressive models Integrated Moving Average (ARIMA) model is in full disregard of independent variables in making the forecast. ARIMA using past and present values of the dependent variables to produce accurate short- 
term forecasting. ARIMA suitable for the observation of time series (time series) are statistically correlated with each other (dependent). (Gudjarati, 1995)

Box-Jenkins models are grouped into three categories:

- Autoregressive Model

- Model Moving Average

- Model Mixed Model mix consists of models Autoregressive-Moving Average (ARMA) and the model Autoregressive Integrated Moving Average (ARIMA).

Autoregressive models (AR)

Autoregressive method is a model that describes that the dependent variable is influenced by the variable itself dependent on previous periods, or autocorrelation can be interpreted also as a linear correlation time series with time series itself with a time difference (lag) $0,1,2$ period or more. Common forms of order $p$ autoregressive with or written with $\mathrm{AR}(\mathrm{p})$ or ARIMA (p, 0,0) has the following equation:

$$
X_{t}=\mu+\phi_{1} X_{t-1}+\phi_{2} X_{t-2}+\cdots+\phi_{p} X_{t-p}+e_{t}
$$

Specification:

$\mathrm{Xt}=$ Value Series variable that will be projected

$\mu=$ constant value

$\phi=$ parameter aoutokorelasi to $\mathrm{i}$

$\mathrm{e}=$ error term

\section{Mean Model Move / Moving Average (MA)}

Moving averaging method (Moving Average) has the general shape with regular order $\mathrm{q}$ or written with MA (q) or ARIMA $(0,0, q)$ is as follows:

$X_{1}=\mu+e_{t}-\theta_{1} e_{t-1}-\theta_{2} e_{t-2}-\cdots . . \theta_{q} e_{t-q}$

Specification:

$\mathrm{Xt}=$ Value Series variable that will be projected

$\mu=$ constant value

$\theta=$ parameter aoutokorelasi to $\mathrm{i}$

$\mathrm{e}=$ error term

Differences moving average and autoregressif models lies in the type of independent variables in the model is autoregressive previous value (lag) of the dependent variable $(\mathrm{X})$ itself, on the model of the moving average as the independent variable is the residual value in the previous period.

ARIMA model projections stages:

a) Determine the best model to estimate the magnitude of the projected variables. To see the goodness of the model used used statistical $F$ test and test of determination (R2) of the estimation model of $\mathrm{Ar}$ $(1,0,0)$ models MA $(0,0,1)$ or the Arima models $(1,0,1)$.

b) The best model is used then made projections by first doing expand the data until 2020.

c) The next test is to compare the suitability of behavioral data with the behavior of the value of the projected results.

\section{RESULTS AND DISCUSSION}

Levy Potential Mapping

Mapping the potential types of potential revenue sources of revenue based on Law No. 28 Year 2009 regarding the levies, where there are 30 (thirty) types of levies while the levies in Cianjur, where there are 19 types. Of the 19 levies were included into several criteria. Levies are included in the category of seed / Prima there are 4 types of levies such as: 1). Market services; 2). Retribution Recreation and Sports; 3). Building Permit levy; 4). Disturbance Permits. Rretribusi included in the Potentials category there are two (2) types: 1). Slaughterhouse levy; 2). Regional Business Sales Production levy. While other levies are levies are included in the category Emerging as many as three types of levies such as: 1). Retribution Health Services; 2). Pengujuan levy motor vehicles; 3) Control .Retribusi Telecommunication Tower. While the rest belongs to the category of Least Developed consisting of 11 types of levy. Were included into the category of backward addressing that not maximal absorption levy, whether it is based on the contribution and growth relatively smaller than the average contribution and development of other levies, as well as due to other factors such as not / do not levy charges in accordance with existing rules in provisions Law No. 28 of 2009

Potential Levies in Cianjur

Prima criteria

1. levies Slaughterhouse ;

2. Retribusi Enterprises Production Sales Regions.

Potential

1. Retribution Market Service Fees;

2. Retribution Recreation and Sports ;

3. Retribution Permits Building ;

4. Retribution Permits Disturbance;

Retarded

1. Retribution Health Service ;

2. Retribution Control Telecommunication Tower

3. Retribution Testing of Motor Vehicles;

Developing

1. Retribution Replacement Cost Print ID Card / Certificate Capil (is not subject to the levy)

2. Retribution Funeral Service and corpse incineration;

3. Retribution Service Fees Waste / Health

4. Retribution Service Fees for parking at Bank Public Road;

5. Retribution Reimbursement Print map; (Not imposed levies)

6. Retribution Liquid Waste Processing; (Not imposed levies)

7. Retribution Service Fees Tera / Tera Birthday; (Not imposed levies)

8. Retribution Education Service

9. Retribution Use Local Resources;

10. Retribution Wholesale Market and / or shopping; (Not imposed levies)

11. Retribution auction place ; (Not imposed levies)

12. Retribution Terminal;

13. Retribution Special place parking;

14. Retribution Accommodation / Guest Houses / Villa; (Not imposed levies)

15. Retribution Ports Service Fees; (Nothing)

16. Retribution Water Crossings; (Nothing)

17. Retribution Permits Points of Sale of Alcoholic Beverages; (Not subject to a levy)

18. Retribution Permits Route

19. Retribution Permits Fishery 
Projection Levy

To make a projection carried estimation method Ordinary Least Square (OLS) by using the software Eviews 6.

The test results and test models projected results levies districts. Cianjur in 2016-2020. Results of the projection processing on the type of retribution then the contribution levy is expected to rise high enough levies building permit (IMB), it is seen from the impact of increased economic development Cianjur Regency so the impact on both the construction of housing, offices and other facilities such as markets. Alteration of the levy increase in building permit (IMB) tersbut visible in the data is quite high, but then decreased until 2020 amounted to $0.13 \%$.

Levy revenue projection is based on the results of the average increase, however, there are types of levies which decreased caused by policy or local regulations Cianjur, such as the type of health care levy where the presence of a health insurance program, the income on health services will certainly decrease. As well as the types of levies that there is the possibility of relative earnings could not be ascertained as retribution burial and incineration of dead bodies. Type levy is expected to experience an increase in types of levies associated with the development and economic development of the region such as garbage and cleanliness retribution, retribution market, parking, IMB and other levies

Table Value Percentage change Value Proyeksi and levies Cianjur Regency Year 2016-2020

\begin{tabular}{|c|c|c|c|}
\hline \multirow{2}{*}{ No } & \multirow{2}{*}{ Code Ret } & \multicolumn{2}{|c|}{ Projected Value Retribution (RP) } \\
\hline & & 2016 & 2017 \\
\hline \multirow[t]{2}{*}{1} & RPK & $4,555,051,379.49$ & $5,099,610,738.81$ \\
\hline & $\%$ & 0.14 & 0.12 \\
\hline \multirow[t]{2}{*}{2} & RPPK & $561,315,826.14$ & $602,842,425.69$ \\
\hline & $\%$ & 0.07 & 0.07 \\
\hline \multirow[t]{2}{*}{3} & RPPPM & $50,936,375.58$ & $55,935,357.63$ \\
\hline & $\%$ & 0.04 & 0.10 \\
\hline \multirow[t]{2}{*}{4} & RPPTJU & $940,266,619.00$ & $1,021,201,894.00$ \\
\hline & $\%$ & 0.09 & 0.09 \\
\hline \multirow[t]{2}{*}{5} & RPP & $1,872,406,546.14$ & $2,008,724,688.33$ \\
\hline & $\%$ & 0.07 & 0.07 \\
\hline \multirow[t]{2}{*}{6} & RPKB & $335,957,220.88$ & $362,018,232.38$ \\
\hline & $\%$ & 0.06 & 0.08 \\
\hline \multirow[t]{2}{*}{7} & RPAPK & $61,541,128.60$ & $66,836,162.75$ \\
\hline & $\%$ & 0.08 & 0.09 \\
\hline \multirow[t]{2}{*}{8} & RPPKS & $49,990,843.00$ & $52,373,917.10$ \\
\hline & $\%$ & 0.04 & 0.05 \\
\hline \multirow[t]{2}{*}{9} & RPMT & $1,955,822,322.20$ & $2,219,297,554.42$ \\
\hline & $\%$ & 0.12 & 0.13 \\
\hline \multirow[t]{2}{*}{10} & RPKD & $36,898,380.39$ & $35,585,117.43$ \\
\hline & $\%$ & $(0.06)$ & $(0.04)$ \\
\hline \multirow[t]{2}{*}{11} & $\mathrm{RT}$ & $312,761,653.54$ & $317,243,164.71$ \\
\hline & $\%$ & 0.01 & 0.01 \\
\hline 12 & RTKP & $492,875,892.07$ & $508,875,925.69$ \\
\hline
\end{tabular}

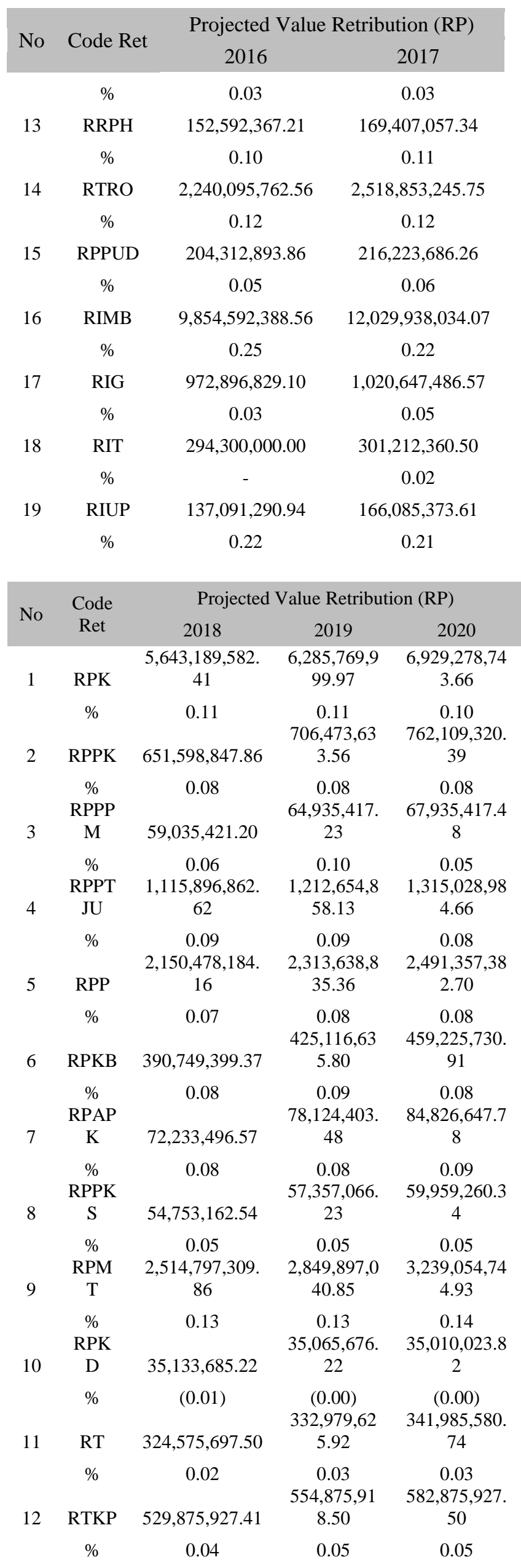




\begin{tabular}{|c|c|c|c|c|}
\hline \multirow{2}{*}{ No } & \multirow{2}{*}{$\begin{array}{l}\text { Code } \\
\text { Ret }\end{array}$} & \multicolumn{3}{|c|}{ Projected Value Retribution (RP) } \\
\hline & & 2018 & 2019 & 2020 \\
\hline 13 & RRPH & $190,873,898.51$ & $\begin{array}{c}216,185,53 \\
1.94\end{array}$ & $\begin{array}{c}246,071,360 . \\
28\end{array}$ \\
\hline 14 & $\begin{array}{c}\% \\
\text { RTR } \\
\text { O }\end{array}$ & $\begin{array}{c}0.13 \\
2,834,320,268 \\
73\end{array}$ & $\begin{array}{c}0.13 \\
3,202,233,1 \\
60.26\end{array}$ & $\begin{array}{c}0.14 \\
3,609,863,72 \\
1.75\end{array}$ \\
\hline 15 & $\begin{array}{c}\% \\
\text { RPPU } \\
\text { D }\end{array}$ & $229,710,946.16$ & $\begin{array}{c}0.13 \\
247,420,76 \\
1.44\end{array}$ & $\begin{array}{c}0.13 \\
268,951,713 . \\
90\end{array}$ \\
\hline 16 & $\begin{array}{c}\% \\
\text { RIMB }\end{array}$ & $\begin{array}{c}0.06 \\
13,982,103,372 \\
.98\end{array}$ & $\begin{array}{c}0.08 \\
15,817,817, \\
807.05\end{array}$ & $\begin{array}{c}0.09 \\
17,816,656,3 \\
25.71\end{array}$ \\
\hline 17 & RIG & $\begin{array}{c}0.16 \\
1,073,199,488 . \\
37\end{array}$ & $\begin{array}{c}0.13 \\
1,132,002,2 \\
67.60\end{array}$ & $\begin{array}{c}0.13 \\
1,196,028,22 \\
8.30\end{array}$ \\
\hline 18 & RIT & $\begin{array}{c}0.05 \\
312,761,972.97\end{array}$ & $\begin{array}{c}0.05 \\
323,572,00 \\
2.54\end{array}$ & $\begin{array}{c}0.06 \\
333,762,000 . \\
28\end{array}$ \\
\hline 19 & RIUP & $199,084,469.49$ & $\begin{array}{c}0.03 \\
237,084,33 \\
1.35\end{array}$ & $\begin{array}{c}0.03 \\
280,084,310 . \\
24\end{array}$ \\
\hline & $\%$ & 0.20 & 0.19 & 0.18 \\
\hline
\end{tabular}

Results Data Processing

\section{CONCLUSION}

a. The potential income levy levy by category are classified as seed / Prima namely 1). Markets Service Fees; 2). Retribution Recreation and Sports; 3). Building Permit levy; 4). Disturbance Permits. While that fall into the category of backward have appreciable amounts of these conditions is due to that there are still many who have not done the withdrawal of levy

b. The results of the projection processing on the type of levy the contribution levy is expected to rise high enough levies building permit (IMB)

\section{SUGGESTIONS}

a. The need for charges made in accordance with the provisions or policies that exist in the district of Cianjur

b. The importance of improvements in targeting, this is an effort to increase revenue.

c. The importance of socialization levy and the application of sanctions on violators

\section{REFERENCE}

[1] Abdul Halim (2001) Pengelolaan Keuangan Daerah. Yogyakarta: UPP AMP YPKN

[2] Ahmad Yani. (2002). Keuangan Hubungan Antara Pemerintah Pusat dan Daerah di Indonesia. Jakarta: Raja Grafindo Persada

[3] Dr. Mulyanto.2002."Potensi Pajak Dan Retribusi Daerah Dikawasan Subosuka Wonosraten Propinsi Jawa Tengah". Jurnal Akuntansi Sektor Publik.
[4] Gujarati, Damodar N. 1995. Ekonometrika dasar Terjemah Sumarbo Zain. Jakarta Erlangga.

[5] Riwu Kaho, Josef, Prospek Otonomi Daerah di Negara Republik Indonesia, 1988)

[6] UU No. 28 Tahun 2009

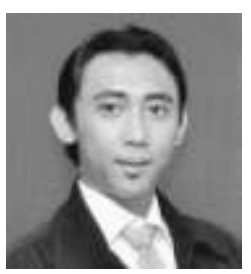

The author was born in Subang, West Java , Indonesia in 1978. He ME in Economics Master planning in Applied Economics from the University of Padjadjaran , in 2012 Since 2004 he is a researcher planning Economics, he has been a lecturer at the college from 2006 in various universities in Bandung, West Java. He is active in various associations such as the Indonesian Economists Association ( ISEI ), the Board of Experts in West Java Economic Forum ( FEJ ) and a research consultant. His research interests include regional planning, public sector economy, local economic development and entrepreneurship . 